\title{
Morphological study of fruits, seeds and embryo in the tropical tribe Dipterygeae (Leguminosae-Papilionoideae)
}

\author{
Estudo morfológico de frutos, sementes e embriões na tribo tropical Dipterygeae \\ (Leguminosae-Papilionoideae)
}

\author{
Rafael Barbosa Pinto ${ }^{2,3}$, Vanessa Maria da Costa Rodrigues Francisco ${ }^{1}$ \& Vidal de Freitas Mansano ${ }^{1}$
}

\begin{abstract}
This work analyses and describes fruit, seed and embryo morphology of 12 Dipterygeae species. The fruit is quite distinct among genera, being a legume in Taralea, a drupoid legume in Dipteryx and a cryptosamara in Pterodon. It was observed that the three genera present distinct morphological characteristics in the epicarp, mesocarp and endocarp. These structures are strongly associated with the dispersal syndromes presented by the genera. Embryonic descriptions are provided for the first time in this manuscript for the three genera presented here and the main diagnostic characteristics are: (1) a gradual extent of development of the hypocotyl-radicle axis from Taralea (undeveloped) to Dipteryx (the most developed); (2) the plumules are entire in Taralea and pinnate in Dipteryx and Pterodon; (3) a cleft below the hypocotyl-radicle axis in Taralea, absent in the other genera, because of the strongly cordate base of the cotyledonar leaves; (4) differences in the degree of development of the hypocotyl-radicle axis between D. alata, D. rosea and D. micrantha. Dipterygeae presents a noticeable diversity of fruit, seed and embryo, Taralea being the most distinct of all. The results of this morphological analysis suggest an evolutive path for the diaspores in the clade, based on phylogenetic studies which show Taralea as sister to the clade constituted by Dipteryx and Pterodon.
\end{abstract}

Key words: diaspores, dispersion, taxonomy, Fabaceae.

\section{Resumo}

O presente trabalho analisa e descreve a morfologia de frutos, sementes e embriões de 12 espécies de Dipterygeae. O fruto é consideravelmente distinto entre os gêneros, sendo um legume em Taralea, um legume drupoide em Dipteryx e uma criptossâmara em Pterodon. Foi observado que os três gêneros apresentam características morfológicas distintas no epicarpo, mesocarpo e endocarpo. Essas estruturas são fortemente associadas com as síndromes de dispersão apresentadas pelos três diferentes gêneros. Descrições completas dos embriões são apresentadas pela primeira vez neste manuscrito para os três gêneros e as principais características diagnósticas encontradas são: (1) um gradual desenvolvimento do eixo hipocótilo-radícula de Taralea (não desenvolvido) a Dipteryx (bem desenvolvido); (2) as plúmulas são inteiras em Taralea e pinadas em Dipteryx e Pterodon; (3) uma fenda abaixo do eixo hipocótiloradícula em Taralea, ausente nos outros dois gêneros, devido à base fortemente cordada das folhas cotiledonares; (4) diferenças no grau de desenvolvimento do eixo hipocótilo-radícula entre D. alata, D. rosea e D. micrantha. Dipterygeae apresenta uma notável diversidade de frutos, sementes e embriões, sendo os mais distintos encontrados em Taralea. Os resultados destas análises morfológicas sugerem um caminho evolutivo para os diásporos dentro do clado, com base nos estudos filogenéticos que apontam Taralea como irmã do clado constituído por Dipteryx e Pterodon.

Palavras-chave: diásporos, dispersão, taxonomia, Fabaceae.

\footnotetext{
${ }^{1}$ Instituto de Pesquisas Jardim Botânico do Rio de Janeiro, DIPEQ, R. Pacheco Leão 915, 22460-030, Rio de Janeiro, RJ, Brazil.

${ }^{2}$ Universidade Estadual de Campinas, Inst. Biologia, Depto. Biologia Vegetal, Programa de Pós-graduação, C.P. 6109, Campinas, SP, 13083-970, Brazil.

${ }^{3}$ Autor para correspndência: rafaelbpinto@gmail.com
} 


\section{Introduction}

Dipterygeae is a basal tribe of the subfamily Papilionoideae (Pennington et al. 2001; Wojciechowski et al. 2004) and is distributed from Central to South America. It is constituted by three genera: Dipteryx Schreb., Pterodon Vog. and Taralea Aubl. (Polhill 1981; Polhill 1994; Barham 2005). In the phylogeny of Cardoso et al. (2012) Monopteryx Spruce ex Benth. appeared as sister of the other Dipterygeae, although the branch is still weakly supported and the type species of the genus was not sampled in that study. So we still do not know if Monopteryx is monophyletic and if it is indeed sister of Dipterygeae clade. The tribe is a monophyletic group according to the phylogenetic analysis by Pennington et al. (2001), Wojciechowski et al. (2004) and Francisco (2010). The genera Dipteryx and Taralea occur mainly in the Amazonian moist forest, except for Dipteryx alata which occurs in dry areas of Central Brazil, Bolivia and Paraguay (Barham 2005). By the other hand, the genus Pterodon is common in the phytophysiognomies of the Brazilian "cerrado" (Almeida et al. 1998).

The members of Dipterygeae are generally trees with pinnate and stipulate leaves, the leaflets are opposite or alternate, without stipels. Dipteryx and Taralea present thick leaves with an alate rachis, while in Pterodon, the leaves are thin with a marginate rachis. The inflorescence is paniculed, the flower presents a calyx with the two adaxial lobes enlarged and the three inferior ones very reduced and a papilionaceous corolla (Polhill 1981). According to Francisco (2010) the flower has an extremely uniform structure among the three genera, and they can be distinguished only by the gynoecium morphology. Taralea has an hairy ovary which is as long as wide, while in Pterodon and Dypteryx the ovary is glabrous and longer than it is wide. Unlike the uniformity of the flower, the fruit is variable among the genera and is a potential source of characters for phylogenetic studies. The genus Taralea, for example, is characterized by the dehiscent fruits known as legumes, while Pterodon and Dipteryx have indehiscent fruits. In Pterodon the fruits are samaroids (cryptosamara according to Barroso et al. 1999) and Dipteryx is drupaceous (Barroso et al. 1999).

Seed and embryo characters have been traditionally used in legume taxonomy. Many authors, including Gunn (1981), Lima (1985), Lima (1989), Oliveira (1999), Kirkbride et al.
(2003), and Meireles \& Tozzi (2008) have shown the importance of such characters to legume taxonomy. Besides taxonomic information, the morphological analysis of fruits and seeds can provide ecological characteristics such as the type and capability of dispersion of the species (Van der Pijl 1956). In Dipterygeae we can find quite distinct dispersal patterns of the diaspores, where the typical genus Dipteryx, presents barochory, followed by a zoochorical sencondary dispersion (Almeida et al. 1990; Vieira-Jr. et al. 2007) or hydrochory (Ducke 1940). Pterodon is a typical genus of the open vegetation of the Brazilian "cerrado". Its fruits, classified as cryptosamara by Barroso et al. (1999), present the prerequisites for anemochory according to Janzen (1980) and finally, in Taralea, the fruits are elastically dehiscent, being it a characteristic of autochory, characterizing what Van der Pijl (1982) called ballistic dispersal. With this wide morphological variation, this paper aims to amplify the knowledge of the morphology of the fruits, seeds and embryo of the tribe Dipterygeae and allow relevant information for taxonomic and phylogenetic studies of the group.

\section{Material \& Methods}

The vouchers of analyzed material are: Dipteryx alata Vogel: BRASIL. MARANHÃO: Alto Parnaíba, 22.III.1978, fr., C. A. Miranda 137 (RB); MATO GROSSO: Cáceres, Porto Limão, 03.III.2004, fr., M.A. Carniello 101 (RB); MATO GROSSO: Cuiabá, Rondonópolis, 1.II.1986, fr., A.M. Carvalho 2175 (RB); MATO GROSSO DO SUL: Campo Grande, Campus da UFMS, 28.III.2007, fr., H.C. de Lima 6582 (RB); MATO GROSSO DO SUL: Nova Adralina, 28.III.1986, fr., U. Pastore \& R.M. Klein 82 (RB); MINAS GERAIS: Paracatu, 22.V.2010, fr., $A$. Quinet et al. 2065 (RB); MINAS GERAIS: Pirapora, Rio das Pedras, 19.VII.1937, fr., M. Burret 10091 (RB); MINAS GERAIS: Três Marias, 12.VII.2005, fr., R.C. Forzza et al. 4002 (RB); PARÁ: São Felix do Xingú, 12.VI.1978, fr., C.S. Rosário 52 (RB); TOCANTINS: Lagoa da Confusão, Ilha do Bananal, Parque Nacional do Araguaia, 26.III.1999, fr., M. A. da Silva et al. 4156 (RB).

D. magnifica Ducke: BRASIL. AMAZONAS: Manaus, Reserva Florestal Adolpho Ducke, 9.XI.2008, fr., L.P. de Queiroz et al. 13912 (INPA, RB); PARÁ: Rio Tapajós, 27.VIII.1916, fr., $A$. Ducke 16400 (RB).

D. micrantha Harms: PERU. LORETO: Maynas Mishaina, 22.VII.1984, fr., R. Vasquéz 5322 (RB). 
D. odorata (Aubl.) Willd.: BRASIL. AMAZONAS: Boca do Rio Tocantins, 19.XI.1986, fl. and fr., H.C. de Lima 2748 (INPA, RB); AMAZONAS: Santa Izabel do rio Negro, 9.VIII.1987, fr., C.A. Cid Ferreira 9308 (RB); PERU, LORETO: University Arboretum on Rio Nanay, 7.VIII.1972, fl. and fr., T.B. Croat 18863 (RB).

D. punctata (S.F.Blake) Amshoff: BRASIL. AMAZONAS: Manaus, Reserva Florestal Adolpho Ducke, 06.V.1988, fr., D. Coêlho et al. d-24 (INPA, RB); PARÁ: Saracá-Taquera, 30.V.1978, fr., N.T. Silva 4671 (RB), RIO DE JANEIRO: Rio de Janeiro, Jardim Botânico do Rio de Janeiro, 27.IV.1993, fr., D.M. Tourinho 24 (RB).

D. rosea Spruce ex Benth.: BRASIL. AMAZONAS: São Gabriel da Cachoeira, Alto Rio Negro, 30.XI.1987, fr., H.C. de Lima et al. 3357 (INPA, RB).

Pterodon abrubtus (Moric.) Benth.: BRASIL. BAHIA: Brotas de Macaúbas, no date, fl. and fr., B.B. Klitgaard et al. 75 (AAU, K, RB); BAHIA: Poções, no date, fr., S.B. da Silva 99 (RB); PIAUÍ: Caracol, Parque Nacional da Serra das Confusões, 8.IV.2009, fr., G. Martinelli et al. 16245 (RB); PIAUÍ: Guariba, 17.VI.2007, fr., G. Martinelli et al. 16152 (RB); TOCANTINS: Natividade, 24.VII.2007, fr., M.M. Saavedra 494 (RB).

P. emarginatus Vogel: BRASIL. BAHIA: Correntina, 2.III.1991, fr., L.G. Viollati 192 (RB); BAHIA: Formosa do Rio Preto, 21.IV.1998, fr., R.C. Mendonça 3402 (RB); GOIÁS: Niquelândia, Macêdo, 27.VI.1996, fr., M.L. Fonseca et al. 1012 (RB); MATO GROSSO: Xavantina, 1.V.1968, fr., R.R. de Santos 1228 (RB); MINAS GERAIS: Santana do Pirapama, Serra do Cipó, 12.III.2009, fr., D.C. Zappi et al. 2098 (RB); PIAUÍ: Baixa Grande do Ribeiro, Estação Ecológica Uruçuí-Uma, 11.IV.2009, fr., G. Martinelli et al. 16386-a (RB); SÃO PAULO: Bauru, Jardim Botânico Municipal de Bauru, 13.IX.2006, fl. and fr., V.L. Weiser 712 (RB).

P. pubescens (Benth.) Benth.: BRASIL. MATO GROSSO: no date, fr., J.G. Guimarães 308 (RB); MINAS GERAIS: Itapecerica, 30.V.1975, fr., G.G. dos Reis 793 (RB); PIAUÍ: Serra Grande, no date, fr., J.S. Assis 106 (RB); SÃO PAULO: Aramina, Povoado Canindé, 1.VI.1979, fr., J.C.C. Ururahy 07 (RB); SÃO PAULO: Bebedouro, no date, fr., J.G. Guimarães 1485 (RB); SÃO PAULO: Boa Esperança do Sul, Perdizes, 7.VII.1964, fr., J.C. Gomes Jr. 2022 (RB).

Taralea cordata Ducke: BRASIL. AMAZONAS: Presidente Figueiredo, 29.I.1984, fr., H.C. de Lima 2142 (INPA, RB).
T. crassifolia (Benth.) Ducke: BRASIL. RORAIMA: Amajari, Serra Tepequem, 29.XI.1964, fr., B. Maguire 32617 (INPA, RB).

T. oppositifolia Aubl.: BRASIL. AMAZONAS: Manaus, 21.II.1937, fr., A. Ducke 34957 (RB); PARÁ: Belém, 16.II.1923, fr., A. Ducke 17120 (RB); PARÁ: Belém, Utinga, Barragem do Lago Água Preta, 21.XI.1994, fr., S.M. Faria 853 (RB); PARÁ: Melgaço, 13.X.1991, fl. and fr., A.S.L. da Silva 2374 (RB).

Before dissected, the seeds were hydrated by boiling in water until the point that its coat or testa could be removed. The fruits, seeds and embryo were photographed using a digital camera attached to the stereomicroscope Leica CLS 150X.

For the surface analyses (scanning electron microscope - SEM), the material was fixed in FAA 50 (Johansen 1940) for $24 \mathrm{~h}$, dehydrated in an ethanolic series (Tucker 1993), dissected in a stereomicroscope, and critical point dried in a Leica EM CPD 030, mounted in aluminium stubs with carbon conductive adhesive tabs (Ted Pella, Redding, California, USA) and metalized. The samples were coated with gold-palladium in an Emitech K550X (West Sussex, United Kingdom). The micrographis were taken at 15,20 or $30 \mathrm{kv}$ with a Zeiss EVO 40 scanning electron microscope (Zeiss, Thornwood, USA) in the Laboratório de Biologia Estrutual of the Instituto de Pesquisas do Jardim Botânico do Rio de Janeiro, Rio de Janeiro, Brazil.

The following characteristics were observed in this study: fruit shape; epicarp, mesocarp and endocarp consistencies; seed shape; testa structure; hilum, micropile, raphe, aril and lens features; embryo shape; hypocotyl-radicle axis and plumule type.

The terminology adopted for classifying the fruits is based on the work by Barroso et al. (1999) and the descriptions of seeds and embryos are from the paper by Kirkbride et al. (2003).

\section{Results}

Dipteryx Schreb., Gen. Pl. 2: 485. 1791, nom. cons

Figs. 1a-d; 2a-d

Monospermic drupoid legume, indehiscent, globose, slightly compressed dorso-ventrally, circular, eliptic or ovate; calix deciduous; epicarp woody, glabrous when mature, scrub, surface not vesiculose, rugose, brown; mesocarp thick with venated surface, fribose, woody, porous, light brown, sometimes divided into two layers; 

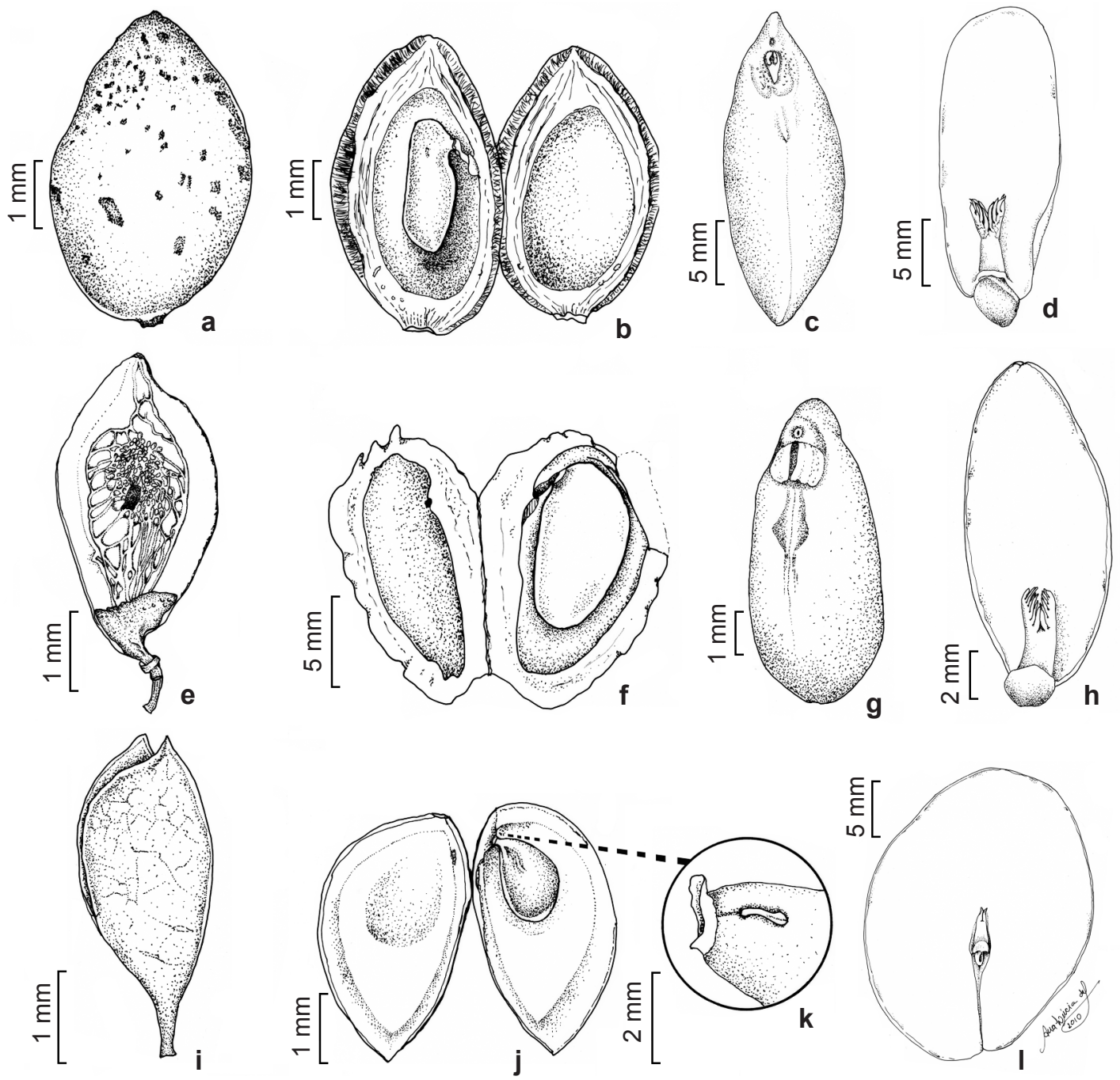

Figure 1 - a-l. camera lucida drawing of fruits, seeds and embryo of Dipterygeae - a. fruit of Dipteryx rosea; b. inner portion of the fruit and seed insertion in D. rosea; c. seed of D. alata; d. embryo of D. alata; e. fruit of Pterodon emarginatus; $\mathrm{f}$. inner portion of the fruit and seed insertion in P. emarginatus; g. seed of P. emarginatus; h. embryo of P. emarginatus; i. fruit of Taralea crassifolia; $\mathrm{j}$. inner portion of the fruit and seed insertion in $T$. crassifolia; $\mathrm{k}$. hilum detail of T. crassifolia; 1. embryo of T. crassifolia (a,b H.C.de Lima 3357; c,d M.A.Carniero 101; e-h R.C.Mendonça 3402; i-1 B.Maguire 32617).

endocarp thin, coriaceous-fibrose, scrub, reddish brown, fused to the mesocarp, not covered by spongy tissue, dehiscent after decomposition of the mesocarp. Seed elliptic to oblong or linear, slightly compressed dorsoventrally, aril absent; testa rugose, coriaceous, black; raphes not visible; hilum elliptic, sub basal or lateral; lens inconspicuous; endosperm absent; embryo straight; cotyledon elliptic, crass, with the external surfaces slightly convex, wrinkled; hypocotyl-radicle axis straight, central on the cotyledons, with ca. 1/5 of the size of the cotyledons; plumule well developed.
Pterodon Vogel, Linnaea 11: 384. 1837.

Figs. 1e-h; 3a-b

Cryptosamara, monospermic, indehiscent, compressed dorso-ventrally, ovate or rarely oblong, centrally inflated; calyx deciduous; epicarp woody, glabrous, surface vesicular, black, splitting irregularly with the external mesocarp; mesocarp thick, venation strongly apparent at the center with balsamic vesicles around the seed chamber, becoming inconspicuous toward the wings; endocarp fibrous or spongeous, coriaceous, winged; 


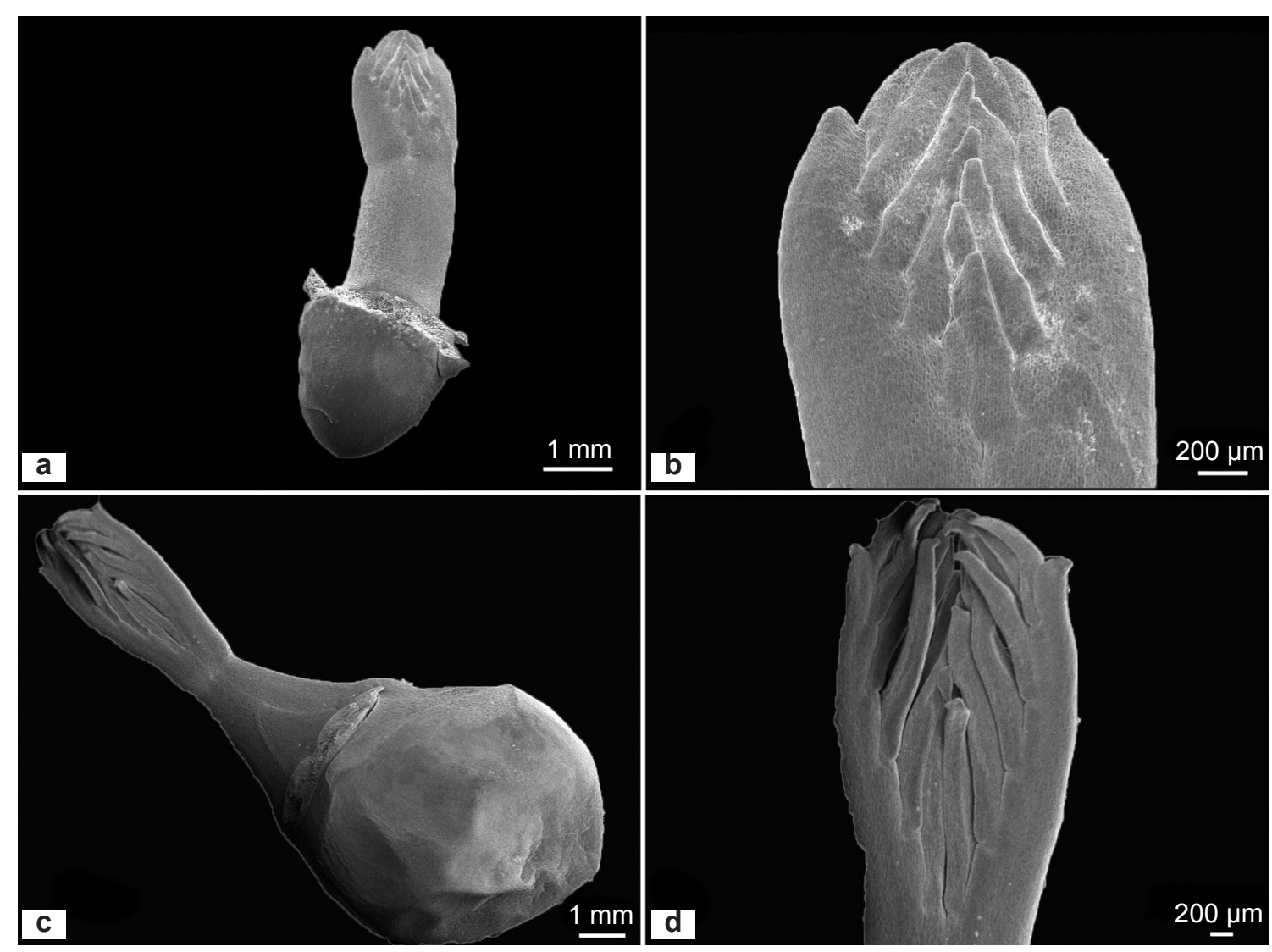

Figure 2 - a-d. SEM of embryos of Dipteryx - a. embryo of Dipteryx alata; b. detail of the plumule D. alata; c. embryo of $D$. micrantha; d. detail of the plumule of D. micrantha.

funicle thick, ca. $2 \mathrm{~mm}$ long. Seed elliptic to oblong, slightly compressed dorsoventrally, with a reduced aril around the hilum; testa smooth, coriaceous, light brown; raphes long, going from the hilum to the base of the seed, darker than the testa; hilum partially or completely hidden by the aril, circular, located on the side of the seed; lens apparent, adjacent to the hilum, oblong to elliptic, darker than the testa; endosperm absent; embryo straight; cotyledons smooth, crass, with the external surfaces convex; hypocotyl-radicle axis straight, central to the cotyledons, with ca. $1 / 4$ of the size of the cotyledons; plumules well developed.

\section{Taralea Aublet, Hist. Pl. Guiane 745. 1775.}

Figs. 1i-1; 3c-d

Monospermic or dispermic legume, with elastic dehiscence, dorsiventrally compressed, asymmetric elliptical; calyx deciduous; epicarp woody, irregular surface, glabrous, black, not brittle; mesocarp thin, woody; endocarp light brown, coriaceous, strongly fused to the mesocarp. Seed circular to ovate, dorsoventrally compressed, aril absent; testa slightly rugose, coriaceous, dark brown to black; raphes inconspicuous; hilum hidden by funicle vestige, circular, basal; lens inconspicuous; endosperm absent; embryo straight; cotyledons ovate or circular, smooth or wrinkled, crass, with the external surfaces slightly convex; hypocotylradicle axis straight, central to the cotyledon, with ca. $1 / 8$ of the size of the cotyledons, having a fissure below the radicle until the half of the cotyledons; plumules poorly developed.

The main diagnostic characteristic of the fruits, seeds, and embryo of Dipterygeae are summarized in Table 1. 


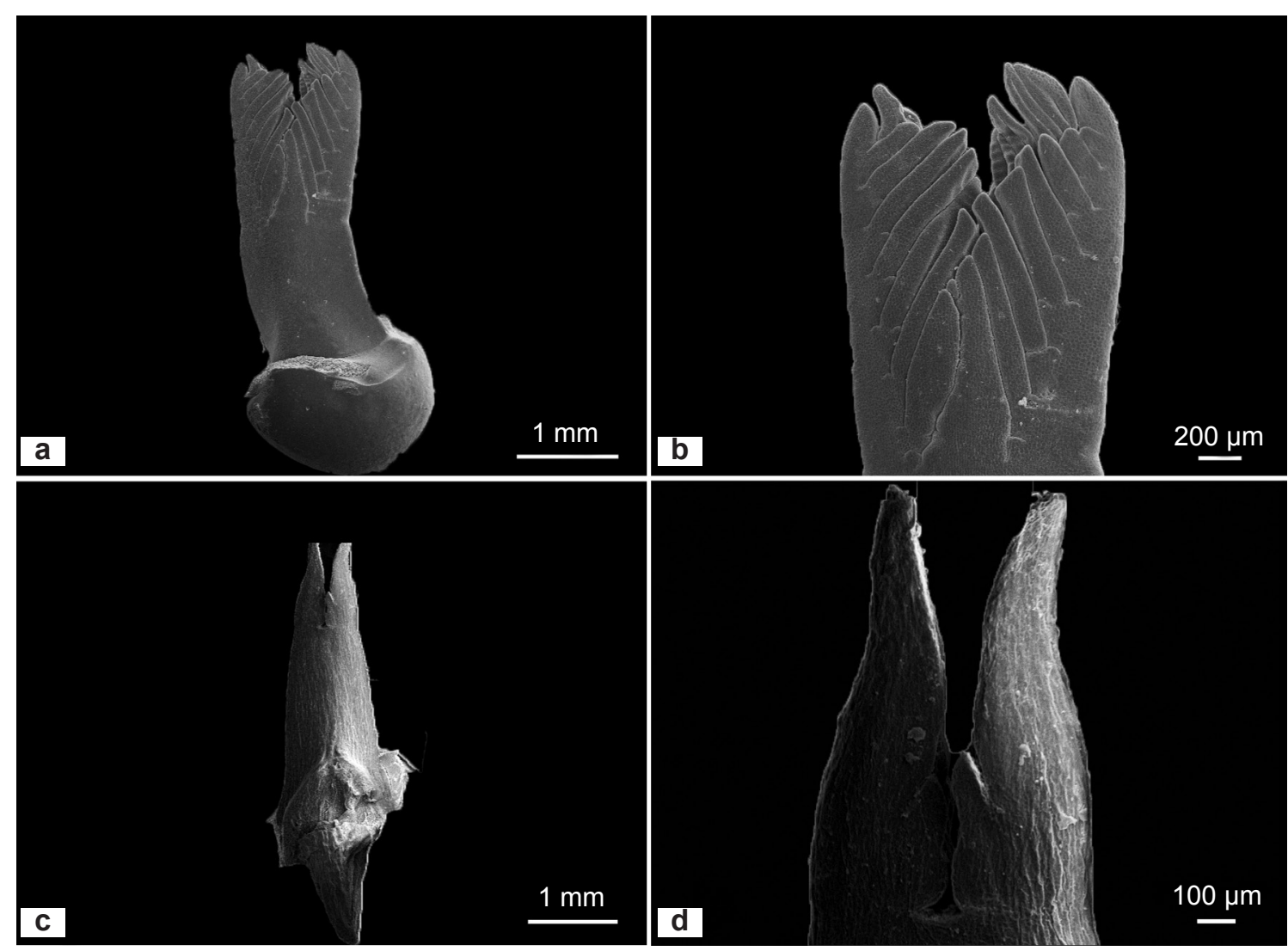

Figure 3 - a-c. SEM of the embryos of Pterodon and Taralea - a. embryo of Pterodon emarginatus; b. detail of the plumule of P. emarginatus; c. embryo of Taralea crassifolia; d. detail of the plumule of T. crassifolia.

\section{Discussion}

Diaspores morphology, dispersal considerations and systematic implications

Leguminosae is a highly heterogeneous family in several aspects. Although the name of the family refers to a type of fruit, its diversity is equally or even higher than other features. Thus, a detailed observation of the external or structural morphology of fruits and seeds is, in some cases, of great importance in the improvement of taxonomic knowledge. In Dipterygeae, the three genera can be promptly distinguished observing the fruit types and seeds morphology, making the study of diaspore morphology very useful taxonomically within the tribe.

Considering the phylogenetic analyses presented by Francisco (2010) and Cardoso et al. (2012) and the results obtained in this paper, it is possible to suggest an evolutionary path of the fruits in this clade. Because they are dehiscent in Taralea, which is sister to the clade composed by Pterodon and Dipteryx, and both have indehiscent fruit, we can infer that the fruit changed from dehiscent to indehiscent within this clade.. The cryptosamaras is a synapormorphy for the species of Pterodon, and the globose and drupoid legume a synapomorphy for the species of Dipteryx.

Fruits in the basal genus Taralea are elastically dehiscent, with a thin pericarp, exposing the seeds during the dispersion (Fig. 1i,j). We emphasize the observation of a persistent portion of the funicle coating the hilum (Fig. 1j,k), which is probably involved in a secondary dispersal by ants (Beattie \& Culver 1982).

The genus Pterodon presents samaras, with a first degradation of the epicarp and mesocarp during the maturity (Fig. 1e). The wing-shaped tissue is the endocarp (Paiva et al. 2008) and it covers a single seed during the dispersion. Then, a second degradation of tissue probably helps the in the seed establishment. For this reason, the 
Table 1 - Morphological characteristics of fruits, seeds and embryo of Dipterygeae genera. $+=$ presence; - = absence.

\begin{tabular}{|c|c|c|c|}
\hline Characters/Genera & Dipteryx & Pterodon & Taralea \\
\hline Fruit type & Drupoid legume & Criptosamara & Legume \\
\hline Dehiscence & - & - & + \\
\hline Epicarp & Non vesicular & Vesicular & Non vesicular \\
\hline Mesocarp & Thick, surface not venated & $\begin{array}{c}\text { Thick, venated surface, showing } \\
\text { balsamic vesicles }\end{array}$ & Thin \\
\hline Endocarp & $\begin{array}{c}\text { Coriaceous-fibrous, scrub, not } \\
\text { covered by spongeous tissue, } \\
\text { dehiscent after decomposition of the } \\
\text { mesocarp }\end{array}$ & $\begin{array}{l}\text { Fibrous or spongy,coriaceous, } \\
\text { winged, fused to the mesocarp }\end{array}$ & $\begin{array}{l}\text { Coriaceous, strongly fused to the } \\
\text { mesocarp }\end{array}$ \\
\hline Seed shape & $\begin{array}{l}\text { Elliptic to oblong or linear, slightly } \\
\text { compressed dorsiventrally }\end{array}$ & $\begin{array}{l}\text { Elliptic to oblong, slightly } \\
\text { compressed dorsiventrally }\end{array}$ & $\begin{array}{c}\text { Circular to ovate, compressed } \\
\text { dorsiventrally }\end{array}$ \\
\hline Testa & Rugose & Smooth & Rugose \\
\hline Aril & - & + & - \\
\hline Raphe & - & + & - \\
\hline Lens & - & + & - \\
\hline Position of the hilum & Sub basal or lateral & Lateral & Basal \\
\hline Embryo texture & Wrinkled & Smooth & Smooth or wrinkled \\
\hline Hypocotyl-radicle axis & $1 / 5$ of the size of the cotyledons & $1 / 4$ of the size of the cotyledons & $1 / 8$ of the size of the cotyledons \\
\hline Plumule & Well developed & Well developed & Poorly developed \\
\hline
\end{tabular}

fruits of Pterodon are referred by Barroso et al. (1999) as a cryptosamara, The samaroid fruits are characterized for being dry and light fruits with shapes that enable the wind to carry the diaspores, which is also called as anemochory (see Vand der Pjil 1982). Anemochory is a syndrome associated with open habitats with absence of physical barriers and wind availability (Janzen 1980) and environments subjected to high wind incidence (Bullok \& Clark 2000; Tackenberg et al. 2003). It can explain the concentrated occurrence of the genus in the Cerrado, a very distinct environment of the Amazonian Forests, the center of diversity of Dipterygeae.

In Dipteryx the fruits are drupaceous, with a very hard and fibrous epicarp and mesocarp (Fig. 1a,b). Among species, the surface of the epicarp seems to have a taxonomic importance in the case of D. alata and D. micrantha, which are grooved externally while the majority of species have a smooth epicarp (Fig. 1a). In this genus, the dispersal of the seeds is primarily barochoric, which needs a long period of tissues degradation to expose the seed; or can be made secondarily by rodents, which also can bury the seeds and improve the range of distances (Forget \& Milleron 1991; Saravy et al. 2003). The seeds of Dipteryx can attract rodents maybe due to the presence of unsaturated oil, protein, calcium and phosphorus, and in the case of $D$. alata and $D$. lacunifera they taste like peanut, being appreciated even by humans (Togashi 1993; Vieira-Jr. et al. 2007). During the study of the diaspores we observed a capability to flotation of $D$. odorata and D. rosea, and in accordance to what was mentioned by Ducke (1940), we suggest the hidrochory as an alternative dispersal syndrome in the Amazonian Forest, once some species are near flooded areas.

A tendency of the fruit tissues to concentrate balsamic resins in the pericarpic vesicles was observed in Pterodon and Dipteryx. As they are lacking in Taralea, but present in the other two genera (Lewis et al. 2005) this can be inferred as a synapomorphy of the clade Pterodon + Dipteryx. Kirkbride et al. (2003) related the presence of balsamic oil ducts in the mesocarp of Pterodon. The essential oil of Pterodon emarginatus is used in some traditional medicine (Brandão et al. 2002). In Dipteryx, the mesocarp is porose (Fig. 1b) with 
sparse oil vesicles, which in $D$. rosea are markedly aromatic and in D. lacunifera the vesicles are well developed.

\section{The seed morphylogy}

Groth \& Liberal (1988) and Barroso et al. (1999) suggest that because the external and internal characteristics of the seeds are less modified by the environment, they constitute secure criteria for families, genera and even species identification and delimitation.

In Dipterygeae the seed characters are source of important diagnostic characters. In Taralea for example, seeds are compressed and the hilum is basal (Fig. 1j,k) while in the other genera the seeds are more dilated and the hilum is lateral (Table 1). The seeds of Taralea present variation concerning the testa color being black in $T$. reticulata and pale-brown in T. crassifolia. Seeds of Pterodon are in general uniform, but there are color variations among species. However, structures such as lens and raphe are apparent, the last one occurring from the lateral hilum to the seed base. A relevant and unique character of the genus is the presence of the aril coating the hilum (Fig. 1g). This reduced aril can be associated with secondary dispersal (Westoby et al. 1982). The presence of these characters can be used to identify the genus within the tribe. For Dipteryx seeds, a relevant taxonomic characteristic for species identification was observed on the surface of the testa, which is foveolate in D. alata with a gradual reduction of this characteristic in $D$. micrantha, D. odorata and D. rosea.

\section{Embryo morphology}

and taxonomic considerations

The embryo of the tribe presents typical characteristic of Leguminosae such as the endosperm lacking, crass cotyledons and a welldeveloped plumule. However, their morphology show a clear distinction among genera, where a gradual extent of development of the hypocotylradicle axis was verified, being undeveloped in Taralea, becoming more evident in Pterodon than in Taralea and strongly evident in Dipteryx where it is more distinct than in the two other genera (Figs. 2a-d, 3a-d). It was observed a gradual fusion of the plumules, where in Taralea they are entire, without the pinnate pattern of the primary leaves as was observed in the two other genera. This characteristic can be interpreted as a plesiomorphy within the group (Figs. 2a-d, 3a-d), once this genus appears as basal within the tribe in the phylogenies of Pennington et al. (2001), Francisco (2010) and Cardoso et al. (2012)

In Taralea, the most distinctive characteristic found is the cleft below the hypocotyl-radicle axis (Fig. 11). Such cleft is because of the strongly cordate base of the cotyledonar leaves, and because of it the lateral basal portions of the blades are longer than the hypocotyl-radicle axis in initial stage. This characteristic is exclusive to the group.

Despite the embryos of the different species of Dipteryx present a superficial resemblance, we found differences in the degree of development of the hypocotyl-radicle axis between $D$. alata and D. micrantha (Fig. 2a,c). It was also observed that $D$. rosea presents a degree of development in the hypocotyl-radicle axis between $D$. alata and $D$. micrantha (not shown).

So, we conclude that the study of fruit, seed and embryo morphology can provide good diagnostic characters to distinguish among the different genera of the tribe and also to differentiate species within each genus.

\section{Acknowledgments}

We are grateful to Frederick Joyner for helping with the improvement of the English text, to Msc. Nina Attias and Dr. Márcia Attias for the help with the images edition and to Ana Lúcia Souza for the skilled illustrations. We are also grateful to the reviewers for their helpful considerations on the manuscript. This paper is part of Vanessa M. da Costa Rodrigues Francisco Master's thesis developed in Botanical School of Jardim Botânico do Rio de Janeiro and was supported by CNPq.

\section{References}

Almeida S.P.; Silva J.A. \& Ribeiro J.F. 1990. Aproveitamento alimentar de espécies nativas dos Cerrados: araticum, baru, cagaita e jatobá. $2^{\mathrm{a}}$ ed. Embrapa/CPAC, Distrito Federal, Planaltina. 83p.

Almeida S.P.; Proença C.E.B.; Sano S.M. \& Ribeiro J.F. 1998. Cerrado: espécies vegetais úteis. EmbrapaCPAC, Distrito Federal, Planaltina. 464p.

Barham J. 2005. Tribo Dipterygeae. In: Lewis G.P.; Schrire B.D.; Mackinder B.A. \& Lock J.M. (eds.). Legumes of the world. Royal Botanic Gardens, Kew. Pp. 250-251.

Barroso G.M.; Morim M.P.; Peixoto A.L. \& Ichasso C.L. 1999. Frutos e sementes: morfologia aplicada à sistemática de dicotiledôneas. UFV, Viçosa. 443p.

Beattie A.J. \& Culver D.C. 1982. Inhumation: how ants and other invertebrates help seeds. Nature 1: 297. 
Brandão, M.; Laca-Buendia, J.P. \& Macedo, J.F. 2002. Árvores nativas e exóticas do estado de Minas Gerais. Informe Agropecuário 23: 264-265.

Bullock J.M. \& Clark R.T. 2000. Long distance seed dispersal by wind: measuring and modeling detail of the curve. Oecologia 124: 506-521.

Cardoso D.; Queiroz L.P.; Pennington R.T.; Lima H.C.; Fonty, E.; Wojciechowski M.F. \& Lavin, M. 2012. Revisiting the phylogeny of papilionoid legumes: New insights from comprehensively sampled earlybranching lineages. American Journal of Botany 99: 1991-2013.

Ducke A. 1940. Revision of the species of the genus Coumarouna Aubl. or Dipteryx Schreb. Tropical Woods 61: 1-10.

Forget P.M. \& Milleron T. 1991. Evidence for secondary seed dispersal by rodents in Panama. Oecologia 87: 596-599.

Francisco V.M.C.R. Filogenia molecular e morfológica da tribo Dipterygeae (Papilionoideae, Leguminosae). Dissertação de Mestrado. Escola Nacional de Botânica Tropical, JBRJ, Rio de Janeiro. 77p.

Groth. D. \& Liberal, O.H.T. 1988. Catálogo de identificação de sementes. Fundação Cargill, Campinas. 182p.

Gunn C.R. 1981. Seeds of Leguminosae. In: Polhill, R.M. \& Raven, P.H. (eds.). Advances in legume systematics, part 2. Royal Botanic Gardens, Kew. Pp. 913-925.

Janzen D.H. 1980. Ecologia vegetal nos trópicos. EPU/ Ed. da Universidade de São Paulo, São Paulo. 79p.

Johansen D.A. 1940. Plant microtechnique. McGrawHill, New York. 523p.

Kirkbride, J.H.; Gunn, C.R. \& Weitzman, A.L. 2003. Fruits and seeds of genera in the subfamily Faboideae (Fabaceae). U.S. Department Agriculture Technical Bulletin 1890: 1-212.

Lewis, G.P.; Schrire, B.D.; Mackinder, B.A. \& Lock, J.M. 2005. Legumes of the world. Royal Botanic Gardens, Kew. 577p.

Lima, M.P.M. 1985. Morfologia dos frutos e sementes dos gêneros da tribo Mimoseae (Leguminosae Mimosoideae), aplicada à sistemática. Rodriguésia 37: 53-78.

Lima, H.C. 1989. Tribo Dalbergieae (LeguminosaePapilionoideae) - morfologia dos frutos, sementes e plântulas e sua aplicação na sistemática. Arquivos do Jardim Botânico do Rio de Janeiro 30: 1-42.

Meireles, J.E. \& Tozzi, A.M.G.A. 2008. Seed and embryo morphology of Poecilanthe (Fabaceae, Papilionoideae, Brongniartieae). Botanical Journal of the Linnean Society 158: 249-256.

Paiva, E.A.S.; Oliveira, D.M.T. \& Machado, S.R. 2008. Anatomy and ontogeny of the pericarpo of Pterodon emarginatus Vogel (Fabaceae, Faboideae), with emphasis on secretory ducts. Anais da Academia Brasileira de Ciências 80: 455-465.

Pennington, R.T.; Lavin, M.; Ireland, H.; Klitgaard, B.B.; Preston, J. \& Hu, J.M. 2001. Phylogenetic relationships of basal papilionoid legumes based upon sequences of the chloroplast trnL intron. Systematic Botany 26: 537-556.

Polhill, R.M. 1994. Classification of the Leguminosae. In: Bisby, F.A.; Buckingham, J. \& Harbone, J.B. (eds.). Phytochemical Dictionary of the Leguminosae. Chapman \& Hall, New York. Pp. 35-50.

Polhill, R.M. 1981. Dipterygeae. In: Polhill R.M., Raven P.H. Advances in legume systematics, part 1. Royal Botanic Gardens, Kew. Pp. 231-232.

Saravy, F.P.; Freitas, J.; Lage, M.A.; Leite, S.J.; Braga, L.F. \& Sousa, M.S. 2003. Síndrome de dispersão em estratos arbóreos em um fragmento de floresta ombrófila aberta e densa em alta floresta-MT. Alta Floresta 2: 1-12.

Tackenberg, O.; Poschiod, P. \& Bonn, S. 2003. Assessment of wind dispersal potential in a plant species. Ecological Monographs 73: 191-205.

Thiers, B. [continuously updated]. Index Herbariorum: A global directory of public herbaria and associated staff. New York Botanical Garden's Virtual Herbarium. Available in <http://sweetgum.nybg. org/ih/> . Access on 6 Feb 2013..

Togashi, M. 1993. Composição e caracterização química e nutricional do fruto do baru (Dipteryx alata Vog.). Tese de Mestrado. UNICAMP, Campinas. 125p.

Tucker, S.C. 1993. Floral ontogeny in Sophoreae (Leguminosae, Papilionoideae). I Myroxylon (Myroxylon group) and Castanospermum (Angylocalyx group). American Journal of Botany 80: 65-75.

Van der Pijl, L. 1956. Classification of the leguminous fruits according to their ecological and morphological properties. Proccedings Akademic va Wetenschppen 59: 301-313.

Van der Pijl, L. 1982. Principles of dispersal in higher plants. Springer-Verlag, Berlim. 161p.

Vieira-Jr., G.M.; Rocha e Silva, H.; Bittencourt, T.C.; Chaves, M.H. \& Simone, C.A. 2007. Terpenos e ácidos graxos de Dipteryx lacunifera Ducke. Química Nova 30: 1658-1662.

Westoby, M.; Rice, B.; Shelley, J.M.; Haig, D. \& Kohen, J.L. 1982. Plant's use of ants for dispersal at West Head, NSW. In: Buckley, R.C. (eds.). Ant-plant interactions in Australia. Junk Press, The Hague. Pp. 75-87.

Wojciechowski, M.F.; Lavin, M. \& Sanderson, M.J. 2004. A phylogeny of legumes (Leguminosae) based on analysis of the plastid matK gene resolves many wellsupported subclades within the family. American Journal of Botany 91: 1845-1861. 